\title{
Manajemen Komunikasi pada Petugas Kebersihan Kota Palembang
}

\author{
Dwi Maharani \\ Fakultas Ilmu komunikasi, Universitas Bina Darma, Jl. Ahmad Yani No.3. Plaju \\ Email: dwimaharani2@yahoo.co.id
}

\begin{abstract}
Abstrak. Petugas kebersihan kota atau biasa disebut dengan "pasukan kuning" adalah sebutan bagi kelompok profesi yang bekerja untuk membersihkan sampah perkotaan di kota Palembang. Berbagai macam stereotip dan prasangka muncul di masyarakat ditujukan pada pekerja kebersihan. Bahwa para pekerja kebersihan kebanyakan berasal dari mayarakat kurang mampu yang belum bisa keluar dari garis kemiskinan, memiliki latar belakang pendidikan yang rendah bahkan sama sekali tidak pernah mengenyam pendidikan, kemudian karena pendidikan rendah serta faktor kemiskinan, mereka juga bertempat tinggal di pemukiman yang kurang bersih. Sebagai realitas yang bermakna sosial, pekerjaan sebagai petugas kebersihan kota merupakan sebuah profesi. Secara umum tujuan penelitian ini : adalah untuk mengetahui bagaimana manajemen komunikasi yang terjadi atau berlangsung pada petugas kebersihan kota Palembang. Teori yang digunakan yaitu teori manajemen komunikasi dan menggunaakan metode penelitian kualitatif. Teknik pengumpulan data yang digunakan yaitu wawancara secara mendalam, pengamatan langsung dan studi dokumentasi. Hasil penelitian yang diperoleh yaitu: manajaemen komunikasi pada petugas kebersihan kota Palembang cukup beragam dilihat dari komunikasi antar pribadinya.
\end{abstract}

Kata kunci: manajemen komunikasi, petugas kebersihan, kota Palembang.

\begin{abstract}
Public cleaning service or commonly referred to as "yellow troops" is the name for a group of professions working to clean up urban trash in the city of Palembang. Various kinds of stereotypes and prejudices arise in the community aimed at public cleaning service. Public cleaning service come from underprivileged people who have not been able to get out of the poverty line, have low educational background and never even received any education, because of low education and poverty factor, they also live in less clean settlements. As a socially meaningful reality, work as a public cleaning service is a profession. In general, the purpose of this study: is to find out how the management of communication that occurred on public cleaning service of Palembang city. The theory used is communication management theory and used qualitative research methods. Data collection techniques used was in-depth interviews, direct observation and documentation study. The result of the research is: communication management on the public cleaning service of Palembang city quite diverse as seen from interpersonal communication.
\end{abstract}

Keywords : management communication, public cleaning service Palembang city. 


\section{PENDAHULUAN}

Sebagai gambaran, Palembang sebagai kota metropolitan dengan penduduk lebih dari 1,8 juta jiwa tidak bisa menolak munculnya berbagai masalah sosial, baik masalah kemiskinan, kriminalitas maupun masalah kesehatan dan kebersihan lingkungan. Masalah kebersihan berkaitan erat dengan masalah sampah yang ada di perkotaan. Volume sampah yang dihasilkan di Palembang berasal dari rumah tangga (domestik), kegiatan fasilitas sosial, perkantoran, pasar, pertokoan, jalan raya dan kegiatan lainnya (non-domestik) mencapai lebih dari 1.200 ton//perhari pada tahun 2015 (Berita Pagi, 2015).

Menariknya, dengan tingkat volume timbunan sampah yang sangat tinggi di Palembang, tidak memberikan peluang bagi Palembang menjadi kota kumuh. Bahkan sebaliknya, hampir setiap tahun Palembang meraih piala Adipura. Tentu, pencapaian tersebut ada andil dari para pekerja atau petugas kebersihan yang dikerahkan setiap hari oleh Dinas Kebersihan Kota.

Petugas kebersihan kota atau biasa disebut dengan "pasukan kuning" adalah sebutan bagi kelompok profesi yang bekerja untuk membersihkan sampah perkotaan. Sebagai pekerjaan dan sumber mata pencaharian, membersihkan sampah adalah aktivitas rutin yang dilakukan setiap hari dari subuh hingga malam hari. Mulai dari pukul 04:00 WIB hingga pukul 23:00 WIB secara bergantian. Pekerja menggunakan seragam berwarna kuning dilengkapi dengan sapu lidi, serok dan karung sampah sudah menjadi bagian dari simbol yang tidak bisa dipisahkan dari pekerjaan ini.

Dari istilah "pasukan kuning" sendiri memberikan gambaran bahwa, "pasukan" dalam Kamus Besar Bahasa Indonesia (KBBI) berarti sekumpulan prajurit atau sekelompok orang atau laskar yang memiliki keberanian dan keahlian khusus untuk melakukan penyerangan atau perlawanan. Kata "kuning" sendiri merujuk pada ikon warna kuning, dalam arti pada saat seseorang menyebutkan kata "kuning" maka yang terbayang dalam pikiran adalah sesuatu yang mewakili kata "kuning" tersebut, yakni warna kuning. Tidak tahu secara pasti siapakah pertama kali yang memopulerkan sebutan "pasukan kuning" yang mengacu pada sebutan untuk petugas kebersihan. Berbeda dengan sebutan yang ada di Surabaya, orang lebih mengenal petugas kebersihan dengan sebutan "cak koen" (cak=kakak dan koen=kamu).

Berbagai macam stereotip dan prasangka muncul dimasyarakat ditujukan pada pekerja kebersihan. Bahwa para pekerja kebersihan kebanyakan berasal dari mayarakat kurang mampu yang belum bisa keluar dari garis kemiskinan, memiliki latar belakang pendidikan yang rendah, bahkan sama sekali tidak pernah mengenyam pendidikan, kemudian karena pendidikan rendah serta faktor kemiskinan, mereka juga bertempat tinggal di pemukiman yang kurang bersih. Kondisi tersebut seolah menjadi segi tiga yang tidak bisa dipisahkan satu sama lain yang melekat pada para pekerja kebersihan.

Jika memang demikian, menjadi sangat menarik untuk dikaji secara mendalam, bagaimana petugas kebersihan menempatkan diri dalam dunia sosialnya. Di satu sisi, mereka bekerja sebagai petugas kebersihan yang berkontribusi membersihkan setiap sudut kota dan lingkungan masyarakat kelas menengah dan atas, akan selalu terlibat interaksi dengan masyarakar kelas atas dan berpendidikan tinggi. Sementara di sisi lain, mereka belum bisa keluar dari masalah yang mereka sedang alami, yakni kemiskinan, pendidikan rendah dan lingkungan yang tidak bersih.

Akibat dari proses tindakan sosial tersebut melalui interaksi atau 
komunikasi antara para pekerja akan membentuk makna subjektif, yang menurut schutz (Kuswarno, 2009) bahwa makna subjektif bukan ada pada dunia privat, personal atau individual. Makna subjektif terbentuk dalam dunia sosial oleh aktor berupa sebuah "kesamaan" dan "kebersamaan" (common and shared) di antara para aktor, dalam hal ini adalah para pekerja kebersihan kota.

Komunikasi, menurut Effendy (2011), adalah proses penyampaian pesan yang dilakukan seseorang kepada orang lain, dengan tujuan untuk memberitahukan, mengubah sikap, pendapat atau perilaku orang tersebut. Penyampaian pesan dapat dilakukan secara lisan (langsung) maupun melalui media (tidak langsung). Pada prosesnya, komunikasi memiliki tujuan, yaitu; (1) Menetapkan dan menyebarkan maksud dari suatu usaha, (2) Mengembangkan rencana-rencana untuk mencapai tujuan yang telah ditetapkan, (3) Mengorganisasikan sumber daya manusia serta sumber daya lainnya secara efektif dan efisien, (4) Memilih, mengembangkan serta menilai anggota organisasi, (5) Memimpin, mengarahkan, memotivasi, serta menciptakan suatu iklim kerja dimana setiap orang dapat memberikan kontribusi.

Selaras dengan tujuannya,
komunikasi memiliki beberapa
fungsi, antara lain fungsi informasi,
fungsi komando akan perintah, fungsi
memengaruhi dan penyaluran, serta
fungsi integrasi.

Proses komunikasi akan efektif jika komunikator melakukan peranannya, sehingga terjadinya suatu proses komunikasi yang baik dan sesuai dengan yang diharapankan, di mana gagasangagasan atau ide dibahas dalam suatu musyawarah antara komunikator dengan komunikan, dan terjadi pemahaman tentang informasi atau segala sesuatu hal menjadi pokok dari pembahasan untuk mengarah pada kesepakatan dan kesatuan dalam pendapat.

Manajemen berasal dari kata dalam bahasa Inggris "management", dengan kata kerja "to manage" yang secara umum berarti mengurusi, mengemudikan, mengelola, menjalankan, membina, atau memimpin. Ada juga pakar yang yang memiliki pandangan bahwa kata manajemen berasal dari bahasa Latin, yaitu "mantis" yang berarti tangan dan "agree" yang berarti melakukan. Kedua kata tersebut digabung menjadi kata kerja "manager" yang berarti menangani (Somad \& Priansa, 2014).

Menurut Somad dan Priansa dengan mengutip beberapa ahli, seperti Aldag dan Stearns (1995), bahwa manajemen adalah suatu proses perencanaan, pengorganisasian, dan penegelola staf, kepemimpinan, dan pengawasan dalam organisasi yang dilakukan secara sistematis guna mencapai tujuan tertentu. Terry (1997) menyatakan bahwa manajemen adalah usaha-usaha untuk mencapai tujuan yang telah ditetapkan lebih dahulu dengan mempergunakan kegiatan orang lain. Sedangkan menurut Stoner dan Freeman (2000) manajemen adalah proses dari perencanaan, pengorganisasian, pemimpinan dan pengawasan pekerjaan anggota-anggota organisasi dan penggunaan semua sumber organisasi yang ada untuk mencapai tujuan organisasi (Somad \& Priansa, 2014).

Terlepas dari pemikiran dan pemahaman yang berbeda dari para pakar tersebut, pada hakikatnya manajemen mengandung dasar falsafah dan unsurunsur yang memiliki kemiripan, yaitu: (Somad \& Priansa, 2014)
a) Manajemen memiliki tujuan yang akan dicapai, yang mana tujuan tersebut telah ditetapkan sebelumnya
(Predetermined Obhectives);

b) Pencapaian tujuan dilakukan 
melalui pendelegasian wewenang kepada pegawai (Through the effort of other people);

c) Pencapaian tujuan organisasi dilakukan melalui fungsi perencanaan, pengorganisasian, pengarahan, kepemimpinan, dan pengawasan, sehingga penggunaan faktor "human" dan "non human" dapat berlangsung secara efektif dan efisien (how to manage of effectively).

Michael Kaye (1994) menyebutkan, Communication management is how people manage their communication processes through construing meanings about their relationships with others in various setting. They are managing their communication and actions in a large of relationship - some personal some professional. (Kuswarno, 2009)

Bagaimana orang-orang mengelola proses komunikasi dalam hubungannya dengan orang lain dalam setting atau konteks komunikasi. Menurut Parag (1999), manajemen komunikasi adalah proses penggunaan berbagai sumber daya komunikasi secara terpadu melalui proses perencanaan, pengorganisasian, pelaksanaan, dan pengontrolan unsurunsur komunikasi untuk mencapai tujuan yang telah ditetapkan. Menurut Antar Venus, Manajemen komunikasi adalah proses pengelolaan sumber daya komunikasi yang ditujukan untuk meningkatkan kualitas dan efektivitas pertukaran pesan yang terjadi dalam berbagai konteks komunikasi. Konteks komunikasi yang dimaksud di sini berarti tataran komunikasi individual, interpersonal, organisasional, governmental, sosial, atau bahkan internasional.

Untuk menjelaskan fenomena petugas kebersihan sampah kota Palembang menggunakan teori manajemen komunikasi dari Michael Kaye. Manejemen komunikasi merupakan suatu bidang terapan yang berkembang terutama di Australia sejak tahun 1980an. Bidang ini dibutuhkan bukan saja oleh kaum profesional, tetapi juga secara personal; bukan saja pada tataran organisasi tetapi juga pada segala bentuk sistem manusia yang bertanggungjawab untuk dapat mengelola komunikasi dengan orang lain (Kuswarno, 2009).

Michael Kaye juga menyebutkan bahwa "what wemust realizeis that the heart of communication is not the surface but in the meanings of interpretations that we ascribe to the message." Adi jantungnya komunikasi terletak pada makna atau interpretasi terhadap pesan. Selanjutnya, Kaye mengungkapkan bahwa ketika pesan dipresentasikan seseorang, interpretasi terhadap pesan tersebut memengaruhi bagaimana orang tersebut harus mempresntasikannya.

Model manajemen komunikasi Kaye dianalogikan dengan sebuah model yang disebut "Boneka Matouschka Rusia" (Russian matouschka dolls). Boneka Matouschka ini adalah boneka yang berasal dari Rusia. Pada Awalnya, di abad 19, seorang pelukis asal Rusia bernama Sergey Malyutin mendapatkan kedua kreasi seni itu. Sebuah inspirasi kemudian melintas di pikirannya. Ia lalu menggambar sosok sebuah boneka kayu dan meminta pemahat bernama Vasiliy Zvyozdotchkin untuk membuatkannya.

Lalu, Malyutin menggambari tubuh boneka tersebut dengan pakaian tradisional wanita Rusia, lengkap berhiaskan kerudung. Dalam gambar tersebut terlihat si wanita sedang mendekap seekor ayam jantan berwarna hitam. Sementara, tujuh 'saudara' dari wanita itu kemudian di simpan di dalam boneka pertama. Mulai dari lakilaki, perempuan, hingga yang terakhir bersosok bayi.

Boneka mainan yang kemudian menjadi sangat digemari oleh anakanak di Rusia itu pun menyimpan pesan 
mendalam tentang kuatnya kasih sayang seorang ibu dan semangat kekeluargaan. Sebuah cara penyampaian yang sangat sederhana, untuk pesan yang begitu mendalam.

Nama Matouschka juga tidak dipilih dengan sembarangan. Konon, di saat boneka itu diciptakan, Matryona adalah sosok wanita cantik yang sangat populer di negeri ini. Nama itu juga menjadi nama umum wanita-wanita Rusia. Serapan dari istilah latin 'mater' yang berarti ibu, pun makin memperdalam makna Matouschka ini (Septianto, 2011).

Selain dalam filosofinya boneka Matouschka mempunyai makna kasih sayang seorang ibu kepada anak-anaknya yang diwujudkan dalam boneka terbesar sampai terkecil. Boneka Matouschka mempunyai makna lain, yaitu konsep manajemen komunikasi sehingga menyadarkan kepada kita bahwa dalam berkomunikasi kita mengawali dengan boneka yang paling dalam (self) yang berarti kita berkomunikasi secara intrapersonal dengan diri kita, dilanjutkan dengan boneka di lapisan yang kedua yaitu interpersonal di mana kita harus mampu berkomunikasi dengan orang lain. Bagian ketiga People in System yang artinya bahwa kita sebagai makhluk sosial hidup dalam sistem/ aturan yang berlaku dalam masyarakat dan yang terakhir adalah Competence Doll yang berarti kemampuan seorang individu untuk melakukan perubahan dalam sistem masyarakat

Berikut penjelasan lebih lanjut mengenai lapisan yang terdapat pada boneka Matouschka menurut Kaye, pada boneka Rusia ini terdapat empat ukuran lapisan atau lapisan pada boneka ini, lapisan yang lebih besar merupakan pelapis atau penutup (casing) bagi boneka yang lebih kecilnya, seperti pada GAMBAR 1.

Ukuran boneka terkecil, mewakili diri (self). Pengetahuan dan pemahaman

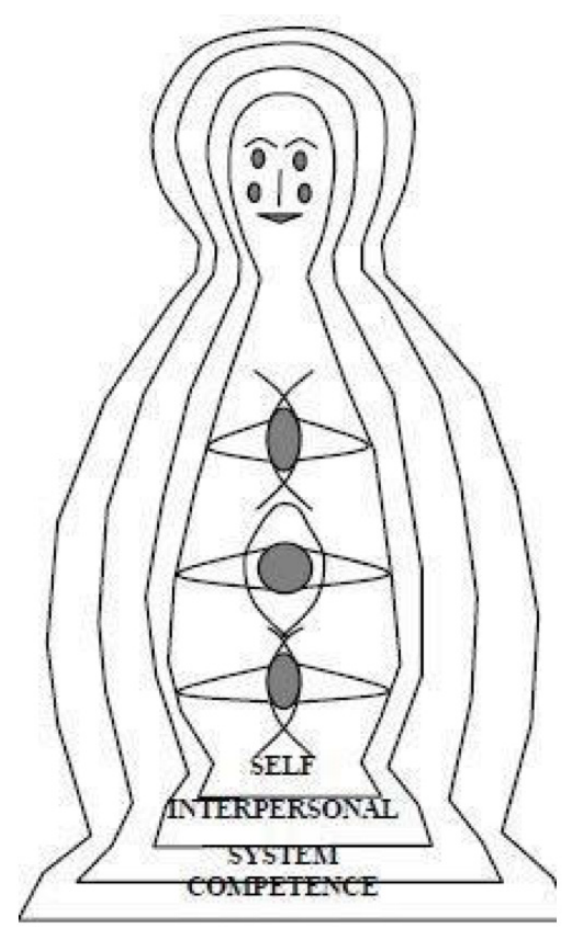

GAMBAR 1. Model Manajemen

Komunikasi Kaye (Kuswarno, 2009)

tentang self seseorang sangat diperlukan untuk menuju pada tahap keberhasilan pengelolaan diri (self-management) orang tersebut. Kesadaran diri (selfawareness) merupakan dasar bagi analisis diri (self-analysis) dan pengujian diri (self-examination). Khususnya ketika seseorang memikirkan bagaimana ia memengaruhi orang lain melalui tindakan atau kata-kata. Dengan kata lain boneka self ini adalah komponen intrapersonal dari model manajemen komunikasi.

Boneka kedua yang menutupi boneka self tersebut adalah boneka interpersonal. Pada bagian ini titik perhatiannya adalah bagaimana self berhubungan dengan orang lain. Elemen interpersonal ini merupakan penjelasan terbaik terhadap pengertian komunikasi sebagai sebuah proses interaksi individu dalam menciptakan makna di antara mereka dan tentang sifat dan keadaan hubungan antarmereka. Boneka 
interpersonal ini menggambarkan bagaimana komunikasi antarmanusia dapat memengaruhi satu sama lainnya dan bagaimana mereka berubah sebagai hasil interaksi di antara mereka.

Boneka ketiga yang menutupi boneka interpersonal adalah boneka "masyarakat di dalam sistem" (people in system). Pada lapisan ini perhatian ditunjukkan kepada bagaimana sistem manusia (human system) atau organisasi di mana masyarakat bekerja dan berfungsi dapat memengaruhi bagaimana orang akan berkomunikasi dengan lainnya dalam keseluruhan sistem tersebut.

Boneka keempat, yang meliputi ketiga boneka sebelumnya disebut boneka kompeten (competence dolls). Pada lapisan boneka ini bukan sekedar penutup bagi boneka lainnya, tetapi menunjukkan bahwa kompeten dalam manajemen komunikasi meliputi seluruh lapisan atau ukuran boneka sebelumnya. Selain itu, dia kompeten memahami dan menampilkan kemampuan (ability) untuk mengubah sistem sosial secara keseluruhan.

Penelitian ini membahas tentang manjemen komunikasi pada petugas kebersihan kota Palembang dengan menggunakan teori manajemen komunikasi dari Kaye. Menurut Kaye, manajemen komunikasi diibaratkan seperti boneka Russian Matouschka yang terdapat 4 lapisan boneka seperti yang telah dijelaskan di atas. Penelitian ini hanya berfokus pada lapisan kedua yaitu komunikasi interpersonal.

Komunikasi interpersonal ialah komunikasi yang berlangsung antara individu dengan individu lainnya. Komunikasi interpersonal merupakan pengiriman pesan dari seseorang dan diterima oleh orang lain dengan efek dan feedback yang langsung. Komunikasi interpersonal sangat efektif dalam mengubah sikap atau prilaku karena satu sama lainnya terlibat komunikasi yang tinggi. Komunikasi interpersonal berlangsung secara tatap muka dan langsung. Melalui komunikasi interpersonal, seseorang dapat membuat dirinya tidak merasa terasing dari lingkungan di sekitarnya. Terdapat lima sikap positif yang mendukung komunikasi interpersonal, yaitu: (1) Keterbukaan; Keterbukaan ialah sikap dapat menerima masukan dari orang lain, serta berkenan menyampaikan informasi penting kepada orang lain. Hal ini tidaklah berarti bahwa orang harus membuka semua riwayat hidupnya, tetapi rela membuka diri ketika orang lain menginginkan informasi yang diketahuinya. Dengan kata lain, keterbukaan adalah kesedian untuk membuka diri mengungkapkan informasi yang biasanya disembunyikan, asalakan pengungkapan diri informasi ini tidak bertentangan dengan asas kepatutan. Sikap keterbukaan tersebut ditandai adanya kejujuran dalam merespon segala stimuli komunikasi. (2) Empati; Empati adalah kemampuan seseorang untuk merasakan kalau seandainya menjadi orang lain, dapat memahami sesuatu yang sedang dialami orang lain, dapat merasakan apa yang dirasakan orang lain, dan dapat memahami sesuatu persoalan dari sudut pandang orang lain, melalui kacamata orang lain. Orang yang berempati mampu memahami motivasi dan pengalaman orang lain, perasaan dan sikap mereka, serta harapan dan keinginan mereka. (3) Sikap mendukung; Hubungan interpersonal yang efektif ialah hubungan yang terdapat sikap mendukung. Maksudnya masing-masing pihak yang berkomunikasi memiliki komitmen untuk mendukung terselenggaranya interaksi secara terbuka. Oleh karena itu respons yang relavan adalah respons yang bersifat spontan dan lugas, bukan respons bertahan dan berkelit. (4) Sikap positif; Sikap positif nampak dalam bentuk sikap dan prilaku. Dalam bentuk sikap, ditunjukkan bahwa pihak-pihak yang terlibat dalam 
komunikasi interpersonal harus memiliki perasaan dan pikiran positif, bukan prasangka dan curiga. Dalam bentuk perilaku, artinya bahwa tindakan yang dipilih adalah yang relevan dengan tujuan komunikasi interpersonal, yaitu secara nyata melakukan aktivitas untuk terjalinnya kerjasama. (5) Kesetaraan; Kesetaraan ialah pengakuan bahwa kedua belah pihak memiliki kepentingan, kedua belah pihak sama-sama bernilai dan berharga, dan saling memerlukan. Secara alamiah, ketika dua orang berkomunikasi secara interpersonal, tidak pernah tercapai suatu situasi yang menunjukkan kesetaraan atau kesamaan secara utuh di antara kedua belah pihak.

Memahami fenomena tentang apa yang dialami oleh subjek penelitian misalnya perilaku, persepsi, motivasi tindakan, dll., secara holistik, dan dengan cara deskripsi dalam bentuk kata-kata dan bahasa, pada suatu konteks khusus yang alamiah dan dengan memanfaatkan berbagai metode alamiah.

\section{METODE}

Penelitian ini menggunakan metode kualitatif yang bermaksud untuk memahami fenomena tentang apa yang dialami oleh subjek penelitian, misalnya perilaku, persepsi, motivasi, tindakan secara holistik, dan dengan cara deskripsi dalam bentuk kata-kata dan bahasa, pada suatu konteks khusus yang alamiah dan dengan memanfaatkan berbagai metode alamiah.

Penelitian kualitatif adalah suatu makna kognitif, atau makna sosiologis yang hidup dalam alam pikiran informan dan subjek-objek penelitian. Bukan suatu konsep yang justru ditawarkan oleh peneliti untuk dikembangkan saat pengumpulan data. Dalam hal ini persoalan etik dan emik menjadi dua konsep yang harus dapat dipisahkan oleh peneliti saat berada di lapangan ataupun saat menganalisis hasil-hasil penelitian.
Etik adalah norma dan nilai, berhubungan dengan apa yang seharusnya akan dilakukan, sedangkan emik berhubungan dengan apa yang dipahami, dimaknai, dan dirasakan oleh informan dan subjek-objek penelitian sebagaimana yang mereka maksudkan. Jadi, konsep kualitatif menjelaskan dan merumuskan pemahaman makna tentang emik, bukan etik. Konsep emik akan mengungkapkan dunia rasional pemaknaan informan dan subjek-objek penelitian terhadap diri mereka dan lingkungannya terhadap fenomena yang menjadi realitas sosial yang diteliti (Bungin, 2007).

\section{Pendekatan Penelitian}

Mulyana \& Solatun (2007) menjelaskan bahwa penelitian kualitatif merupakan penelitian yang bersifat interpretif (menggunakan penafsiran) yang melibatkan banyak metode dalam menelaah masalah penelitiannya. Cresswell (Mulyana \& Solatun, 2007) mengemukakan lima tradisi penelitian kualitatif: biografi, fenomenologi, grounded theory, etnografi dan studi kasus. Dalam penelitianini, peneliti memilih fenomenologi sebagai pendekatan metode penelitian.

Fenomenologi tidak berasumsi bahwa peneliti mengetahui arti sesuatu bagi orang-orang yang sedang diteliti. Inkuiri fenomenologis dimulai dengan diam. Diam merupakan tindakan untuk menangkap pengertian sesuatu yang sedang diteliti, terutama aspek subjektif dari perilaku orang. Agar lebih menguatkan pemahaman peneliti akan perilaku subjeknya, maka peneliti berusaha untuk masuk ke dalam dunia konseptual para subjek yang ditelitinya sedemikian rupa sehingga peneliti mengerti apa dan bagaimana suatu pengertian dikembangkan oleh pelaku atau subjek penelitian.

Pendekatan fenomenologi mengasumsikan manusia sebagai 
makhluk yang kreatif, bekeinginan bebas, dan memiliki beberapa sifat subjektif lainnya. Fenomenologi bertujuan untuk mengetahui dunia dari sudut pandang orang yang secara langsung mengalaminya atau berhubungan dengan sifat-sifat alami pengalaman manusia, dan makna yang ditempelkan padanya. Dengan demikian penelitian fenomenologi harus menunda proses penyimpulan mengenai suatu fenomena, dengan menempatkan fenomena tersebut terlebih dahulu dalam tanda kurung, atau dengan kata lain mempertanyakan dan meneliti terlebih dahulu fenomena yang tampak, dengan mempertimbangkan aspek kesadaran yang terdapat padanya (Kuswarno, 2009).

\section{Teknik Pengumpulan Data}

Untuk memperoleh data yang digunakan dalam penyusunan penelitian ini maka, dilakukan pengambilan data secara primer dan sekunder, yaitu : (1) Data Primer, adalah data yang diperoleh langsung peneliti dari subjek yang diteliti. Adapun data primer yang didapat peneliti adalah dari hasil observasi langsung di lapangandan wawancara secaramendalam dengan informan yang menjadi subjek penelitian, yaitu para petugas kebersihan Kota Palembang; (2) Data Sekunder yaitu sumber data penelitian yang diambil secara tidak langsung melalui media perantara (diperoleh dan dicatat oleh pihak lain) yaitu dari dokumen dan studi pustaka, baik yang dipublikasikan dan tidak dipublikasikan. Dalam penelitian ini, data sekunder yang digunakan adalah dari dokumentasi, sumber pustaka, data statistik, dan lain-lain.

\section{HASIL DAN PEMBAHASAN}

Manajemen komunikasi pada petugas kebersihan kota Palembang dari sudut pandang komunikasi interpersonal antara petugas dengan atasan, petugas dengan teman sejawat, dan petugas dengan masyarakat sekitar tempat bekerja, serta komunikasi organisasi pada petugas kebersihan kota Palembang.

Dalam komunikasi interpersonal dilihat dari lima sikap positif yang mendukung komunikasi interpersonal tersebut, komunikasi interpersonal antara petugas dengan koordinatornya berjalan dengan baik, namun masih kurang masksimal dalam sikap mendukung. Karena koordinator juga tidak memiliki kemampuan secara penuh untuk mendukung kebutuhan (yang diperlukan) oleh para petugas kebersihan secara maksimal. Koordiantor hanya dapat mendukung petugas kebersihan dengan menyampaikan aspirasi dari petugas kebersihan kepada Dinas Tata Kota Palembang. Keterbukaan, kemampuan untuk membuka diri petugas kebersihan dan koordinator lapangan berlangsung dengan cukup optimal. Terutama, hal ini terjadi pada petugas kebersihan di lingkungan GOR Sriwijaya, di mana setiap hari petugas dapat bertemu dengan koordinatornya pada saat melakukan absen masuk dan pulang, serta dapat berkomunikasi langsung dengan koordinatornya di saat petugas memiliki "unek-unek" mengenai lingkungan tempat mereka bekerja maupun mengenai pengunjung atau masyarakat yang ada di sekitar tempat mereka bekerja.

Berdasarkan hasil observasi, komunikasi yang terjadi cukup cair, petugas kebersihan dapat menyampaikan saran, keluhan, maupun hambatan saat melakukan tugasnya kepada koordinator. Selain itu, juga tidak hanya membicarakan tentang "tugas", namun juga diselingi dengan obrolan tentang kehidupan sehari-hari, yang juga terdapat gurauan di dalamnya. Koordinator dan petugas kebersihan sama-sama memiliki kebutuhan berkomunikasi untuk menyampaikan atau menerima informasi, baik mengenai lingkungan tempat bekerja maupun mengenai peralatan atau fasilitas 
untuk melakukan pekerjaan.

Sedangkan komunikasi yang terjadi di antara petugas terlihat lebih cair dan sederhana, banyak terdapat "gurauan" dalam obrolan yang mereka lakukan. Di antara sesama petugas komunikasi jauh lebih terbuka, baik tentang keluhan mengenai pekerjaan samapai juga pada persoalan pribadi. Sedangkan interaksi yang berlangsung (terjadi) antara petugas kebersihan dengan masyarakat yang ada di ingkungan sekitar tempat mereka bertugas cendurung jarang melakukan komunikasi. Petugas kebersihan jarang sekali memulai percakapan dengan masyarakat sekitar. Lebih sering terjadi percakapan jika masyarakat sekitar yang terlebih dahulu menyapa/ menegur. Komunikasi yang terjadi antara masyarakat dengan petugas kebersihan juga sering terjadi menggunakan komunikasi nonverbal, yaitu melalui senyuman atau hanya tatapan mata.

Empati, petugas dan koordinator memiliki kemampuan untuk memikirkan apa yang dipikirkan oleh rekan sesamanya, koordinator dan petugas kebersihan mampu untuk merasakan apa yang dirasakan oleh rekannya. Kemampuan yang optimal untuk mendengarkan dan merasakan, yang pada akhirnya ada rasa saling menghargai dan menghormati, sehingga para petugas saling bekerjasama dengan baik dan dengan cara yang bersahabat. Namun, empati yang sama tidak terjadi anatara petugas dengan masyarakat, ada masyarakat yang dapat berempati terhadap petugas dan ada juga yang tidak.

Hal ini nampak dari tindakan atau perilaku masyarakat saat membuang sampah. Mereka (masyarakat) masih banyak yang membuang sampah tidak sesuai dengan tempat yang disediakan, sampah yang mereka buang mereka lemparkan sembarangan (tidak ke dalam bak penampungan sampah).

Berdasarkan hasil observasi, masih terdapat masyarakat yang tidak peduli terhadap kebersihan, di mana saat petugas kebersihan baru saja selesai membersihkan (menyapu) di satu lingkungan, tidak lama setelah itu ada masyarakat yang membuang sampah sembarangan di tempat tersebut. Masyarakat sangat tidak membantu petugas dalam menjaga kebersihan lingkungan, bahkan mereka terlihat biasa saja saat membuang sampah dari sisa makanan mereka. Hal ini sangat tidak berempati terhadap petugas kebersihan dalam mendukung petugas kebersihan menjaga kebersihan, serta kurangnya penghargaan dan rasa menghargai dari masyarakat terhadap petugas kebersihan, terutama dari kalangan masyarakat yang tergolong usia muda.

Menurut Suranto Aw (2011) sikap mendukung ditunjukkan dalam bentuk sikap dan perilaku. Koordinator dapat memberikan kesempatan kepada petugas kebersihan secara langsung dalam memberikan atau menyampaikan gagasan dan ide. Namun, petugas kebersihan tidak dapat menyampaikan kapan pun gagasan ataupun ide secara langsung kepada atasan mereka, yaitu pada Dinas Tata Kota Palembang. Petugas kebersihan dapat bersura hanya disaat tertentu ketika mereka dilibatkan di beberapa forum, itu pun yang diambil hanya beberapa saja perwakilan dari petugas. Sikap mendukung yang diberikan masyarakat pada petugas kebersihan terlihat dari perilaku masyarakat yang membuang sampah pada tempat yang telah disediakan, meskipun belum semua masyarakat yang menyadari bahwa kita harus membuang sampah pada tempatnya. Petugas keberihan mendukung masyarakat dengan cara menjaga kebersihan lingkungan tempat mereka tinggal dengan ikhlas dan senang hati.

Sikap positif, pimpinan mempercayai petugas kebersihan 
terhadap apa yang dilakukan dengan cara memberikan motivasi anggota untuk mencapai tujuan dan dapat melaksanakaan tugas lebih baik lagi dari sebelumnya. Seperti, yang dialami oleh Ibu Tatri yang mendapatkan kesempatan diumrohkan oleh Gubernur Sumatera Selatan. Sikap positif yang dilakukan petugas atas tanggung jawabnya sebagai petugas kebersihan yaitu dengan menjaga kebersihan kota Palembang, dan hal ini terbukti dengan dinobatkannya kota Palembang sebagai kota Adipura. Sedangkan sikap positif dari masyarakat yaitu melalui tindakan membuang sampah pada tempatnya serta ada juga masyarakat yang berbagi rezeki (dalam bentuk makananan) pada petugas kebersihan.

\section{SIMPULAN}

Berdasarkan hasil penelitian yang telah dilakukan mengenai manajemen komunikasi petugas kebersihan kota Palembang yang dilihat dari komunikasi interpersonal antara petugas dengan koordinator komunikasi antara sesama petugas kebersihan, dan komunikasi anatara petugas dengan masyarakat cukup berbeda, di mana komunikasi yang terjadi antara petugas kebersihan dengan koordinator lapangan terjadi dengan cukup baik, sedangkan komunikasi yang terjadi anatara sesama petugas kebersihan berlangsung dengan baik, cair dan bersahabat. Sedangkan komunikasi anatara petugas kebersihan dengan masyarakat cenderung tertutup dan kaku.

\section{DAFTAR PUSTAKA}

Aw, Suranto. (2011). Komunikasi Interpersonal, Yogyakarta: Graha Ilmu.

Berita Pagi. (2015, Desember 07). http:// beritapagi.co.id/2015/07/12/sampahpalembang-capai-1-200-ton-per-hari. html. Diakses pada 2 Juli 2016, http:// beritapagi.co.id/2015/07/12/sampahpalembang-capai-1-200-ton-per-hari. html

Bungin, B. (2007). Penelitian Kualitatif: Komunikasi, Ekonomi, Kebijakan. Publikdan Ilmu Sosial lainnya. Jakarta: Putra Grafika.

Effendy, O.U. (2011). Ilmu Komunikasi: Teori dan Prakteknya, Bandung: Remaja Rosdakarya.

Kuswarno, E. (2009). Metode Penelitian Komunikasi Fenomenologi:

Konsepsi,Pedoman, dan Contoh Penelitiannya. Bandung: Widya padjajaran.

Mulyana, D., \& Solatun. (2007). Metode Penelitian Komunikasi. Bandung: PT. Remaja Rosdakarya.

Parag, D. (1999). Communication Management, Kuala Lumpur: Golden Books.

Septianto, M. I. (2011, Maret 16). The Phenomenon. Diakses pada 24 April 2018, http://mizwarilmi. blogspot.co.id/2011/03/managemenkomunikasi-dalam-boneka.html

Somad, R.,\&Priansa,D.J.(2014). Manajemen Komunikasi, Mengembangkan Bisnis Berorientasi Pelanggan. Bandung: Alfabeta.

Venus, Antar. 2009. Manajemen Kampanye: Panduan Teoritis dalam mengefetifatikan Kampanye Komunikasi. Jakarta: PT.Simbiosa Rekatama Media 